\title{
Development and Policies of New Energy Vehicles in China
}

\author{
Lin Sun \\ Institute of National Economy, Shanghai Academy of Social Sciences \\ 7/622, Huaihai Zhonglu, Shanghai 200020, China \\ Tel: 86-21-5306-1696 E-mail: sunlin@sass.org.cn
}

Received: October 28, 2011

Accepted: November 21, $2011 \quad$ Published: February 1, 2012

doi:10.5539/ass.v8n2p86

URL: http://dx.doi.org/10.5539/ass.v8n2p86

\begin{abstract}
At present, the issue of how to rapidly develop and popularize new energy vehicles has sparked some hot discussion in Chinese automobile market. The policies promoting the development of new energy vehicles have become the focus concerned by all related parties. This paper introduces the development background and the development status quo of new energy vehicles in China, analyses the current promoting policies and discusses the trend of these policies in future. We deem that the government role, the technological route selection and the system of subsidies and financial funds for private consumption will decide the prospect of new energy vehicle in China.
\end{abstract}

Keywords: Chinese automobile market, New energy vehicles, Policy analysis

\section{Introduction}

The rapid development of China's auto industry commencing from 2002 ushered in the climax in 2010, the automobile production and consumption reached an unprecedented scale. Urban areas in China have only spent 10 years to basically enter an automobile community. The rapid development of automobile industry has driven China's economic growth, promoted the employment, increased tax revenue, and enabled consumers to fully enjoy the convenience of automobile traffic. Meanwhile, it has also brought a series of automobile traffic problems involved in externalities, such as the growth of energy consumption and the deterioration of urban air pollution. Therefore, although the new energy vehicles cannot be used to solve all problems, people have placed great expectations since they do, at least, help energy-saving and emission-reducing, especially in the improvement of urban air pollution. How can new energy vehicles be rapidly developed and popularized in the future, and gradually replace the traditional internal combustion engines that have been developed continuously for more than 100 years? Such an objective has become a long-term goal for the world's auto industry development. To this end, the research, development, production and popularization of new energy vehicles have drawn the active participation of the governments and the global automotive companies, by which substantial investments in R \& D manpower and material resources have been made to strive for the breakthrough obtained in the shortest possible period of time.

As we all know, from 2000, automobile industry in China has just entered the large-scale stage of development. Energy and environmental related policies on auto industry are one decade old. From 1999, the government started to implement the automobile emission limits; from 2004, the automobile fuel economy limits. About how the Chinese government has promoted energy-saving automobiles, Sun (2008) and Sun (2011) have reviewed the policy of China's auto emissions and fuel economy. From 2009, the issue on the rapid development and popularization of new energy vehicles was also one of the hottest spots for the fast-growing auto market in China, while the policies for promoting the development of new energy vehicles became the focus concerned by the auto industry and consumers. But as the new energy vehicles are just starting to enter the market, the relevant policies and standards have not yet formed now. Relevant policy research reviews are also still scarce. Only Xu (2009) briefly summarized the policy, market and industry system of new energy vehicle in China. Zhang (2009) researched the policy of Chinese pure electric vehicles.

In this paper, we will introduce the development background and the development status quo of new energy vehicle in China, and we will also analyze the current promoting policies and discuss the trend of the policy in future. 


\section{The Development Background of New Energy Vehicles in China}

Since 2002, the trend of steep rise of China's automotive market has far exceeded the US market in the 1960s and 1970s, and the Japanese market in the 1970s and 1980s. Taking into account that those large potential groups have planned to buy vehicles, the market size would continue to grow in China. While for the developed countries such as the US and Japan, the auto sales have been related to the replacement of vehicles, and the size of the market has been presented as a stable and a gradual declined one. Thus, although the current vehicle population is less than one-third of that of US, China will finally become, in 20 to 30 years, the world's largest country with the greatest vehicle population (Note 1).

A large-scale car market and the car population mean a huge arisen industry whose industrial spillover effects would include a very wide range of industries of production, sales and after-sales service to spur the economic growth greatly and to increase employment and revenue. Also, it means the huge amount of fuel consumption, oil imports, deteriorating urban atmospheric environment, normalized traffic congestion and multiple traffic accidents. There is no doubt that the arrival of a large-scale automobile society would bring the mobile convenience, but it cannot be avoided that the problems involved in its externalities would trouble the consumers, government and the auto industry itself.

\subsection{Vehicle Fuel Consumption and Oil Imports}

According to the forecast disclosed by Annual Report on China's Energy Development (Cui 2008), China's oil consumption in the period of 2007-2020 would continue to maintain a high growth rate. The report expects that China's oil consumption in 2010 will reach 407 million tons and 563 million tons in 2020, respectively will be increased by $17.42 \%$ and $62.47 \%$ compared with that of 2006 while the refined oil consumption in 2010 will reach 2.2 million tons and 335 million tons in 2020. The annual growth rate of the refined oil demand in the period of 2007-2010 was 5.5\%, but in $2010-2020$, it will be $4.2 \%$, which will be higher than the corresponding year-on-year growth rate of oil demand. Therefore, the refined oil demand will account for a higher proportion of the oil demand, which has increased from $47.1 \%$ of that in 2006 to $54.1 \%$ in 2010 and $59.5 \%$ in 2020 . From the view of refined oil, it is expected that the gasoline demand will grow the fastest by an average annual growth rate of $5.7 \%$ and the diesel fuel's average annual growth rate of $4.2 \%$.

The constant rising proportion of gasoline and diesel oil consumption in oil consumption reflects the growth of vehicle energy consumption. China's gasoline consumption is mainly used in transportation while the diesel oil consumption for transportation, agriculture and construction. In 2008, China's apparent consumption of gasoline and diesel oil respectively reached 63.42 million tons and 138.55 million tons, providing the further rising growth rate by an increase of $14.1 \%$ and $11.7 \%$ respectively. Over $97 \%$ of the total gasoline consumption and $40.7 \%$ of the total consumption of diesel are consumed by vehicle (Zhang, 2009). It is expected that the 2010 auto market will continue to maintain rapid growth in apparent consumption of more than 72 million tons for gasoline throughout the year. Along with the satisfactory development of the industrial and transportation sectors, there is going to be a period strongly demanding diesel and the apparent consumption of diesel throughout the year is expected to be close to 150 million tons (Note 2).

China will face larger scaled vehicle fuel consumption based on a population increased over 10 million cars per year. According to the data predicted by the Chinese State Council Development Research Center that, by 2020, China's auto sales will reach 21.84 million units whose car population will reach 130 150 million units (Note 3). In addition, according to the experts' prediction, the car fuel consumption in 2030 will be five times of that in 2000 based on the existing rising speed of demand of vehicles and the present annual growth rate of $6 \%$ (Jin, 2005). Of course, China's low level of average vehicle fuel consumption is related to the technological level of China's auto industry starting from a low standard and the relevant imperfect policies. Today, the auto consumer market is continually expanding and the auto fuel consumption is constantly rising to cause people to worry about China's energy situation, especially the insurance controlling issues along with the rising dependency of oil imports. Therefore, how to improve the overall average vehicle fuel consumption standards to effectively curb the growth in vehicle fuel consumption has become a top priority task for China's auto industry development.

\subsection{Urban Air Pollution and Vehicle Exhaust Emission}

In China's urban areas, the trend of vehicle emissions is ever-increasing, resulting in severe urban air pollution problems. In some cities, photochemical pollution problems have occurred. Small particulate matter (SPM) has also become an important source of pollution in many cities while the SPM from vehicle emissions reaches a proportion of $20 \sim 30 \%$. According to the experts' prediction, compared with the emission level in 2004, China's vehicle emission of $\mathrm{CO}$ and $\mathrm{NO}_{\mathrm{x}}$ in 2010 will increase by two times and the comprehensive contribution rate of car pollution in cities will reach $79 \%$ (Note 4 ). 
According to the data published by the 1st Chinese National Pollution Census Bulletin (Note 5) for the major pollutants of the emissions of the whole country, the emissions of nitrogen oxides have reached 17.98 million tons, of which 11.88 million tons have been out from industrial sources, 582 thousand tons from livelihood sources and 5.49 million tons from vehicles whose emissions of nitrogen oxides have accounted for $30 \%$ of the total amount, significantly influencing the urban air pollution. In addition, the vehicle emissions include a total amount of 590.6 thousand tons of SPM, 39.47 million tons of carbon monoxides and 4.78 million tons of hydrocarbons as well.

Besides, according to the speech (Note 6) presented to the Standing Committee of the National People's Congress by Shengxian Zhou, the Minister of Environmental Protection Ministry, the vehicle emissions have become an important source of urban air pollution for cities of large and medium sizes. In large cities, air pollution begins to be characterized by coal-burning and vehicle exhaust pollution that will be exacerbated by more difficult treatment. Haze pollution and ozone pollution have become prominent issues in the air pollution of the eastern cities. For Shanghai, Guangzhou, Tianjin, Shenzhen and other cities, hazy days have accounted for $30 \sim 50 \%$ of the total days in a year.

Most cities in China are in the early popularity of the family passenger cars. According to the current speed of popularity, if there are no strict and effective measures taken to control vehicle emissions, the urban air pollution problems caused by the vehicle exhaust emissions will become increasingly serious. There is no doubt that the development of new energy vehicles would help to alleviate China's oil import dependency and the contradiction between domestic energy supply and demand, which would be in line with China's oil insurance strategy. Besides, it will also help reduce the carbon dioxide emissions and harmful exhaust emissions of the transportation sector, and will help improve the atmospheric environment issues, in particular urban air pollution problems.

\section{The Development Status Quo of New Energy Vehicles in China}

In China, the development of new energy vehicles would be of great significance for the development of the entire Chinese auto industry. Firstly, there will be smaller gap between China and other automotive powerhouse countries in the development of new energy vehicles than that in traditional cars. Some domestic experts believe that, compared with developed countries in the aspects of comprehensive technological, commercialization and industrialization factors, China remains an existence of the gap in traditional internal combustion engine vehicles for 20 years, and in the new energy vehicles, there is only a gap for 3-5 years (Yang, 2008). Therefore, it would be a historical opportunity for China to rapidly narrow the gap with the world's advanced level. If the development of new energy vehicles can be accelerated by local maker, China can change in a relatively short period from the current powerful vehicle market into a powerful vehicle producer in the future. Secondly, China is in the initial stage of motorization since car penetration is still very low. Therefore, the new energy vehicle development strategy must provide wider space and the less resistance for the promotion and popularization of new energy vehicles must be beneficial to formation of the industrial scale and market size of new energy vehicles. Thirdly, the auto industry that can reflect the scientific and technological level of a country's development, independent innovation ability and international competitiveness would involves the production of dozens of industries and the employment opportunities of tens of millions. Therefore, the development and popularization of new energy vehicles must present major national strategic significance.

\section{$3.1 R \& D$ and Production of New Energy Vehicles in China}

For all types of new energy vehicles in China, there are enterprises and research institutes engaged in research (Zeng, 2009). Considering from the national strategic perspective, China has started from the "Tenth Five-Year Plan" period to support the research institutions to develop the technological R \& D and commercialization of new energy vehicles by the major project of "863 Plan" of electric vehicles implemented by the Ministry of Science and Technology (Note 7). The major project of "863 Plan" of electric vehicles has selected specially a new generation of electric-vehicle technology as the main innovation direction of auto technologies, including the research objects of pure electric vehicle, fuel cell vehicle and hybrid electric vehicle (He, 2005).

\subsubsection{Hybrid Electric Vehicle (HEV)}

Hybrid electric vehicle, a special project most likely to achieve a breakthrough among the national project of "863 Plan" of electric vehicles, has attracted the concern of major domestic auto manufacturers, such as automotive groups like Dongfeng, FAW, Changan, Chery, BYD, etc., who have developed and produced small quantities of hybrid vehicles (Note 8).

Dongfeng Electric Vehicle Co., Ltd. is one of the automobile companies engaged in electric vehicle research and 
its development started the earliest. It has undertaken two finished-vehicle projects listed as the research and development programs of the "863 Plan" and the Dongfeng-branded hybrid electric cars that are mainly suitable to be used as urban taxis, government vehicles and private cars. Dongfeng-branded hybrid electric buses have been put into demonstration operation, whose level of the entire finished-vehicle has ranked at the leading position.

FAW has assumed the R \& D and production of the "Liberation-brand" hybrid city bus and "Red-flag-brand" hybrid electric car are listed in the "863 Plan". The "Liberation-brand" hybrid city buses have been put into demonstration and the "Benteng-brand" hybrid electric car being developed is expected to be put into market in 2010 .

The Chongqing Chang'an Automobile self-developed hybrid electric car, Jie Xun HEV, which was off the assembly line in December 2007, applies moderate petrol-electric technology and its total fuel consumption is more than $20 \%$ lower than that consumed by a conventional car.

Chery's first type of hybrid electric car, A5BSG (mild hybrid electric car) was off the assembly line in June 2007 officially and A5ISG (moderate hybrid electric car) in October 2007. Such Chery's first type of hybrid electric cars has been put into operation for the taxi market of Wuhu City, Anhui Province.

In January 2008, BYD launched a plug-in hybrid electric F3DM (Dual Mode) at the Detroit International Auto Show, which achieves a true sense of a twin-energy hybrid system $(E V+$ HEV) since it can be recharged or fueled by a variety of ways to add energy. After a variety of testing states of the entire finished-vehicle, it can be driven by pure electric driving basically under the urban road conditions.

\subsubsection{Electric Vehicle (EV)}

The Dongfeng Electric Vehicle Co., Ltd. has developed four major series, nearly 20 varieties of pure electric vehicles, such as excursion buses, sport utility vehicles, industrial vehicles and golf carts and other special. Its self-developed "Shenlong Fukang" pure electric cars are China's first batch of commercialization electric cars ordered by the government authorities.

Tianjin Qingyuan Electric Vehicle Co., Ltd. has undertaken the R \& D of "Xiali pure electric car" listed as a key project of the "863 Plan". The company independently developed S series and B series of pure electric cars and T series of electric mini-trucks have been exported abroad (European and American markets) in batch. By of the end of 2009, the export of Qingyuan electric vehicles had been accumulated for more than 3,000 electric vehicles.

Beijing Institute of Technology, as an undertaking institution for the entire finished-vehicle, has undertaken the "pure electric bus project" listed as the "863 Plan" of electric vehicles during the "Eleventh Five-Year" period. It has completed the development of four kinds of finished buses and passenger vehicles and conducted low-volume pilot production of more than 40 vehicles.

In recent years, pure electric cars beyond the "863" plan have been independently developed by more enterprises. Chery's M1-EV priced around RMB60000 is expected to be put into market in 2010, which can be recharged using civilian $220 \mathrm{~V}$ and charging time is generally $4-6$ hours, a half an hour fast charge can be charged to $80 \%$ of the battery while 100 kilometers consume only 8 degrees of electricity (Note 9).

The price of BYD E6 is expected to be RMB200 thousand, whose endurance miles reach $400 \mathrm{~km}$ while 100 kilometers consume only about 20 degrees of electricity. It is equivalent to one-third to one-fourth of the energy consumption price for a gasoline car. The civilian $220 \mathrm{~V}$ can be used for slow charging and $3 \mathrm{C}$ can be used for fast charging, approximately the battery can be filled into $80 \%$ in 15 minutes (Note 10 ).

"Ben-Ben MINI-EV" produced by Chang'an Automotive Group, an electric vehicle provided with a built-in pure electric drive system, has had its maximum speed up to $120 \mathrm{~km}$ per hour, a charge can furnish a maximum travel of 150 kilometers, and 100 kilometers only consume about 10 degrees of electricity (Note 11).

\subsubsection{Fuel Cell Vehicle (FCV)}

Supported by the national project of "863 Plan" of electric vehicles listed in the "Fifth Five-Year Plan" and the "Eleventh Five-Year Plan", Tongji University, Shanghai Automotive Industry Group and other institutions have applied the way of cooperation, by which the fourth generation of China's hydrogen fuel cell sample-cars bearing completely their independent intellectual property rights have been successfully developed independently. Tsinghua University united a number of component suppliers and a new generation of a fuel cell city bus bearing completely their independent intellectual property rights has been successfully developed jointly with Beiqi Foton Motor Co., Ltd.. Dongfeng Motor Corporation and Wuhan University of Technology have 
jointly developed a hydrogen fuel cell electric vehicle, "Chutian No.1", and so on. In 2008, there were also hydrogen-powered concept cars launched by Chang'an. At present, the hydrogen fuel based fuel cell vehicles are still being developed and produced in the stage of concept cars and prototypes.

In recent years, new energy vehicles have become the auto industry's hottest topics that have been placed by high hopes, tending to be a great spring up all over China. At present, it can be seen from the media coverage that many vehicle manufacturers and non-automotive manufacturers are developing and producing new energy vehicles. Besides, local governments are also actively involved. Such media coverage has reported not only massive investment programs and superior product performance, but also satisfactory market expectations. However, in the past few years, the presence of such sorts of vehicles has been still rarely seen on the market. It is clearly undeniable that there would be the intention of local governments and enterprises using the media speculation about.

It can be seen from the foregoing content that China's main participants of new energy vehicles, particularly the pure electric vehicles, are several types of enterprises. Some of them are relevant research institutions and state-owned companies supported by China's national financial fund to develop electric vehicles, such as Dongfeng Electric Vehicle Co., Ltd.; some are a number of enterprises originally manufacturing electric bicycles; some are those manufacturing electric cells, among whom the most typical and most successful one is BYD Auto whose developed plug-in hybrid electric vehicle.

Starting from the beginning of 2009, China's major production enterprises for passenger vehicles have presented highly their enthusiasm in the R \& D of new energy vehicles. BYD, Chery, Huacheng, Chang'an, Shanghai Automotive, Dongfeng Motor, FAW and other auto companies have all worked out their development strategy for new energy vehicles and mass production vehicle types have been put into the production announcement of auto products. According to the statistics released by relevant authorities, currently in China now, there have been 76 types of new energy cars and buses provided by 27 companies, including hybrid electric vehicles, pure electric vehicles, fuel cell vehicles, etc., published.

\subsection{Government Authorities' Understanding of China's Development Level of New Energy Auto Industry}

On June 17, 2009, the Ministry of Industry and Information Technology released the Admittance Management Rules for New Energy Auto Manufacturing Companies and Products (Rules), in which the scope of new energy vehicles is defined as an involvement of hybrid electric vehicles, pure electric vehicles (BEV, including solar energy cars), fuel cell electric vehicles (FCEV), hydrogen engine cars, vehicles based on other new energy sources.

In addition, the attachment of Rules identifies clearly that the related classification and management will be divided into three different technological stages: the initial stage, the development stage and the mature stage according to the maturity of new energy auto finished-vehicles, the related system and key assembly technology, the perfection extent of the national and industrial standards as well as different levels of industrialization.

The products in the initial stage refer to those whose realization path of technical principles is still in the preliminary study stage because there isn't industrialization condition and it is short of national and industrial standards related. For example, the zinc-air batteries of hybrid passenger car and hybrid commercial vehicles; the nickel-metal hydride battery power of pure electric passenger car and pure electric commercial vehicles. The products in the development stage refer to those whose realization path of technical principles is basically clear and industrialization conditions are available primarily, but national and industrial standards are not perfect. The examples are the lithium-ion power battery of hybrid passenger car and hybrid commercial vehicles, and the lithium-ion power battery of pure electric passenger car. The products in the mature stage refer to those whose realization path of technical principles is clear and both the related technology and production process are mature while the national and industrial standards are basically complete for the entering of the industrialization stage. At present, the technologies classified as meeting the requirement of maturity are only nickel-metal hydride battery based passenger cars, lead-acid battery powered hybrid electric vehicles, and lead-acid battery powered pure electric passenger cars as well as pure electric commercial vehicles.

From the foregoing content, we can find that it is relatively cautious for Chinese government authorities on their understanding of the development of new energy vehicles. Most of other types of new energy vehicles powered by other energy storage devices are defined as that in their initial stage of technology.

\section{The Current Promoting Policies on New Energy Vehicles}

There is no doubt that the government would ultimately strive for the sustainable development in the promotion of the development of new energy vehicles, namely, striving for the goals, by promoting and regulating the new 
energy auto industry into its sustainable development to meet China's national energy strategy, to conserve energy resources and to reduce the dependence on oil resources, of reducing vehicle exhaust emissions and achieving "fuel-consumption-saving and emission-reduction". The relevant policies on new energy vehicles in China are sorted out and analyzed while an outlook on the future policy trend is provided as follows.

\subsection{Course of China's Policies on New Energy Vehicles}

Recalling China's policies on new energy vehicles, although the Chinese government began to support the research activities of new energy vehicles very early, the financial funds applied to support R \& D of new energy vehicle have been used actually starting from the "863 Plan" of electric vehicles. During the period of "Tenth Five-Year Plan", the major scientific and technological projects of electric vehicles under the ministry of Science and Technology were established. As the R \& D strategy and layout of "three vertical and three horizontal", three key vehicle technologies of fuel-cell cars, hybrid vehicles and pure electric vehicles are named as "three vertical", and three key technologies of multi-energy power-train system, driven motor and power battery are named as "three horizontal") (Ouyang, 2006). After three rounds of R \& D, a functional prototype, performance prototype and product prototype of an electric vehicle have been developed. More than 500 units of new energy vehicles were provided to-Beijing Olympics, and were put into operational promotion demonstration in 13 cities. In addition, the Ministry of Industry and Information Technology have commissioned institutions concerned to develop the relevant technological standards for electric vehicles.

Chinese government has started since 2001 when financial funds were used to support the R \& D of new energy vehicles by introducing the "863 Plan" of major projects of electric vehicles during the period of "Tenth Five-Year Plan". The role of policies has resulted in the scope of scientific research institutes and a handful of R \& D departments of state-owned auto companies still. Besides, the first new energy vehicles developed in that initial stage were mainly those fuel cell based vehicles that were expected to achieve a breakthrough in fuel cells of which the fact was not satisfactory.

For the "major projects of energy-saving and new energy vehicles" of the "863 Plan" during the period of the "Eleventh Five-Year Plan", there started the support for R \& D of hybrid vehicles, pure electric vehicles and fuel cell vehicles. Since 2007, the relevant policies for new energy auto industry have been involved gradually in support of the extension direction of industrialization from the original simple support of the research, including admittance management, subsidy policies, demonstration projects and other measures.

In January 2009, the issuance of New Energy Vehicle Demonstration and Promotion Notice began the implementation of subsidies for the purchases of new energy vehicles in the public transportation sector, focusing on the promotion of the formation of new energy auto market. In March the same year, the Auto Industry Restructuring and Revitalization Planning was introduced, which planned to realize the production capacity of 500 thousand vehicles that would account for about $5 \%$ of total vehicle sales at the end of 2011 . In May the same year, the State Council decided to discount by the form of loan arrangement of 20 billion RMB for financial support for auto industry in the technological innovation and the development of auto industry.

Considering the nature of the policies, during the period of "Tenth Five-Year Plan", the policies have gradually begun to enter a co-exist period combining market-based regulatory system and incentives, because of the gradual growth of non-state-owned enterprises and the increasing of enterprises participating in the development of new energy vehicles. For instance, with respect to market admittance regulation, New Energy Vehicle Production Admittance Management Rules was issued in November 2007. It defines the new energy vehicles and stipulates corresponding conditions and requirements on the admittance of new energy auto manufacturers. With respect to the incentive policies, Energy-saving and New Energy Vehicle Promotion Demonstration Financial Assistance Fund Management Provisional Measures was introduced. It clearly defines the conditions and amount of subsidies for a variety of new energy vehicle to encourage enterprises to improve their technological level of new energy vehicles. Energy-saving and New Energy Vehicle Pilot Promotion Demonstration Notice was issued to strengthen the government's mandatory procurement of energy-saving and environmentally-friendly vehicles and the promotion into public transportation sector. Directory of Recommended Types of Energy-saving and New Energy Vehicle Demonstration Projects for Promotion Application was issued to create a consumer demonstration effect.

\subsection{Local Governments' Policies on New Energy Vehicles}

While the local governments actively implement the relevant national policies to encourage the development of new energy vehicles in their promotion of the development of new energy vehicles, they have positively introduced local strategies, policies and measures concerned. So far, Beijing, Shanghai, Chongqing, Jilin, Anhui, Guangzhou, Shenzhen, Wuhan and other cities have developed their policies to encourage and develop their new 
local sources of vehicles, organized their local industrial alliance, published standards of financial subsidies, set up special funds for R \& D and so on. With respect to the encouraging of private consumption of new energy vehicles, local governments no longer wait for policies from the central government, but have begun to refer to the central government's subsidy standards for public sectors purchasing new energy vehicles and have introduced their local subsidy policies for private consumption of new energy vehicles. Chongqing, Guangzhou and other places have formulated relevant policies to encourage private consumption one after the other.

However, policies for new energy vehicles in various regions are presented with strong local flavor. As soon as the central government issued the Energy-saving and New Energy Vehicle Promotion Demonstration Financial Assistance Fund Management Provisional Measure, 13 cities have started the "1000 Vehicles at 10 Cities" program to implement the related subsidies for new energy vehicles. Nevertheless, various cities have had their first batch of new energy vehicles purchased from their local producers. Local governments are optimistic about the prospects for the development of new energy vehicles. The new energy industry has been deemed as a key supporting industry based on that local enterprises of finished-vehicle are the mainstays that have announced to build their new energy auto base. Therefore, there are worries from the field that each pilot city has purchased the local products only considering the local interests of the priority. All of these are not conducive to the improvement of domestic new energy vehicle technology and the industrialization of new energy vehicles (Note 12).

\section{An Outlook for the Policies in Future}

During the period of "Tenth Five-Year Plan", China had once appeared the development craze of "fuel-cell vehicles" which failed to enter the stage of industrialization finally because of technological reasons. Since 2008, the hot spot of new energy vehicles has started turning to hybrid vehicles and pure electric vehicles while the upsurge of developing and producing electric vehicles throughout the country has been formed. From the analysis above we can see that enterprises for producing finished-vehicles and battery-related companies have shown great enthusiasm in new energy vehicles while the related enthusiasm of local governments are also much higher than that of the central government. Then, how has the central government viewed the present situation of the "enthusiasm on new energy vehicles "? What will be the policy tendency in the future? On January 9, 2010, Wei Miao, vice minister of the Ministry of Industry and Information delivered a speech on China's development of new energy vehicles (Note 13). From his speech, a basic understanding of new energy vehicles from the government authorities can be seen and the policy tendency in the future can be speculated.

With respect to the technological standards, Wei Miao said that the relationship between the new energy vehicles and traditional energy ones would be presented as a basic foundation to be improved because new energy vehicles cannot be achieved by leaps and bounds. For the traditional vehicles, there would be many technologies remained not available while for a pure electric vehicle's batteries, electric motors and electric control system, etc., there would be many problems to be solved. In short, the technical aspects of new energy vehicles have not yet stood with the same starting line of international communities as some people say.

With respect to the market size, Wei Miao pointed out that the sales of the real so-called new energy vehicles would only account for a small percentage of the total sales, which would be estimated to be $10-15 \%$ by 2020 . Speaking of the attitude and input from the government during the period of "Eleventh Five-Year Plan", China has spent only 1.1 billion RMB on new energy vehicles and a total amount would be less than 10 billion RMB coupled with those invested on R \& D by enterprises. Based on such a small investment, it cannot be done in any case to realize the industrialization. With respect to the government subsidies, the development of new energy vehicles would not be able to share large amounts of government subsidies for a long time because there would be larger amount extent of subsidies provided firstly while less amount later.

All of these have shown the gaps among central government's, auto companies' and local governments' understanding of the level of technologies, the industrialization and market of China's "new energy vehicles" as well as the financial input and subsidies. Therefore, the future development of China's new energy vehicles may face several aspects as follows.

\subsection{The Positioning of Government Role in the Development Process of New Energy Vehicles}

It can be found in the Auto Industry Restructuring and Revitalization Planning introduced in March 2009, that the government hopes to complete the integration of 14 enterprises into 10 and, within three years, to increase an amount of 10 billion RMB special funds arranged by the central government for technological improvement and transformation to support the key auto manufacturers in their upgrading of products and improving of key technological standards of energy-saving, environmental protection, security and so on. As we can see, the government remains optimistic about its own planning capacity with an intention to continue the domination of 
auto industry mergers and acquisitions and a heavily amounted investment to support the development and expansion of key state-owned enterprises. However, looking back on the development of China's auto industry over the past 20 years, there have not been many facts that can prove that the policies formulated by the government have promoted the industrial development and growth of auto industry of China. Therefore, there are sufficient reasons to suspect that if the following of the same old practices, i.e., huge amounts of capital for research institutions and key state-owned enterprises still provided by the government, will be able to promote the industrialization and market of new energy vehicles in China. It is obvious that those non-key enterprises and private enterprises that have no access to policy funds have to rely on their own investment in the development of new energy vehicles. From the point of view of the market, to continue such support policies would be neither efficiency nor fair. As public resources, government funding should be used more often to improve the market environment. In addition, speaking of the difficulties for the popularization of new energy vehicles, the government should play a major role in the building of social infrastructures for new energy vehicles.

\subsection{Technological Route Selection of China's New Energy Vehicles}

In the enacted Admittance Management Rules for New Energy Auto Manufacturing Companies and Products, the new energy vehicles refer to those in line with the national standards of vehicles in general sense, excluding the low-speed electric vehicles currently developed, produced and sold throughout the country. However, some specialists believe that Chinese consumers will first be exposed to mini-electric passenger cars for 2 to 4 people which can drive $100 \mathrm{~km}-200 \mathrm{~km}$ to meet consumer demand for a home-to-office journey (Note 14). Since the relatively low production cost for a mini-electric vehicle whose price is also relatively inexpensive, it does not require government's subsidy. Specialists also clearly point out that the development of China's electric vehicles may apply an approach of "starting from 2 terminals to the central" (Note 15). That is, firstly promoting at 2 terminals applying mini low-speed electric vehicles, or electric vehicles less demanding on the mileage, and large public transportation buses, and then gradually applying a transition to mid-size vehicles.

We've noted that China's Relevant Standards on New Energy Vehicles haven't been promulgated yet. Taking into account the national booming of low-speed electric vehicles, as well as specialists' opinions about the development paths for electric vehicles in China, the central government would be very careful in the formulation and introduction of relevant standards for new energy vehicles, in particular, the electric vehicles.

\subsection{The Subsidies and Financial Funds for Private Consumption of New Energy Vehicles}

Since China's current auto market has reached 13 million vehicles in size, the private consumption has occupied the absolute dominant position. Therefore, the relevant policies for new energy vehicles must be developed taking private consumption as the object, but no longer just staying in the sectors of public transportation buses and civilian vehicles. However, the expansion of the market of private consumption of new energy vehicles is still facing China's new energy vehicle technology that is not yet fully mature, the related infrastructure construction that has not yet been commenced, the price that is relatively higher and a multiple of other barriers.

In general, both the technological development and infrastructure construction are a gradual process while the too-high price is related to the too-small size of auto industry and market. Nevertheless, the media and public have regarded currently that the most important obstacle is caused by the fact lacking of incentives for private consumption. Some people think that, in China, most of the potential consumer groups for the purchase of new energy vehicles are very sensitive to price. In order to achieve the rapid growth of new energy vehicles, the key factors should include the lower prices of vehicles and the improvement of subsidy policies to reduce the acquisition cost and the driving cost of new energy vehicles (In general, both the technological development and infrastructure construction are a gradual process while the too-high price is related to the too-small size of auto industry and market. Nevertheless, the media and public have regarded currently that the most important obstacle is caused by the fact lacking of incentives for private consumption. Some people think that, in China, most of the potential consumer groups for the purchase of new energy vehicles are very sensitive to price. In order to achieve the rapid growth of new energy vehicles, the key factors should include the lower prices of vehicles and the improvement of subsidy policies to reduce the acquisition cost and the driving cost of new energy vehicles (Fang and $\mathrm{Hu}, 2009$ ). Therefore, including local governments and auto enterprises, all would like the central government to work out the subsidy policies for private purchases of vehicles as soon as possible. However, it can be inferred from the speech mentioned above given by Wei Miao, that since the main problem involved in China's new energy vehicles is the immature technology, it would probably still benefit the multinational corporations if the large-scale subsidies are started at present to benefit the private purchases of vehicles. That situation is not conducive to the development of "self-owned brand" to cause nonconformity with the development strategy for China's national auto industry. In addition, since the number of private purchases is quite different from that of the public transportation sector, once the measures of subsidies are implemented for 
private purchases of new energy vehicles, there will be the guarantee issue of adequate financial subsidy funding.

\section{References}

Cui, Mingxuan. (2008). Annual Report on China's Energy Development 2008. BeiJing: Social Sciences Academic Press (in Chinese).

Fang, Haizhou \& Hu, Yan. (2009). Analysis of the Tax Preferential Policy Effect for the Rapid Promotion of the New Energy Automobile. Automobile Science \& Technology, No. 3:7-10 (in Chinese).

He, Zhisheng. (2005). Development Status and Trends of New Energy Vehicle Technology. Automobile Research \& Development, No. 6: 27-29 (in Chinese).

Jin, Yuefu. (2005). Challenge of Fuel Consumption Faced by the Passenger Vehicle. World Auto, No. 1: 94-95 (in Chinese).

Ouyang, Minggao. (2006). Chinese Strategies and Countermeasures for Energy Saving and Vehicles with New Types Energy. Automotive Engineering, No. 4 (28): 317-321 (in Chinese).

Peng, Xu. (2009). Policy System and Marker related to New Energy Vehicle in China. Automobile \& parts, No. 40: 14-17 (in Chinese).

Sun, Lin. (2008). China's Automobile Traffic Related Problems with the Vehicle Technology Policies. In Miyoshi, H. \& Tanishita, M. (Eds.). Technological Innovation in the Automotive Industry and Economic Welfare (pp. 143-174). Tokyo: Hakuto Shobo Publishing Company (in Japanese).

Sun, Lin. (2011). Transportation Problems and Policy Solutions in China. In Hiroaki, Miyoshi \& Masanobu, Kii (Eds.). Technological Innovation and Public Policy (pp. 171-198). London: Palgrave Macmillan.

Yang, Haixia. (2008). Auto new energy revolution: opportunities for new energy vehicles in China. China Investment, No. 9: 28-37 (in Chinese).

Zeng, Peng. (2009). Status Quo and Problems of the Development of New Energy Vehicle in China. Shanghai Auto, No. 8: 5-7 (in Chinese).

Zhang, Xiang. (2009). Policy of Pure Electric Vehicles in China. Tianjin Auto, No. 11: 19-22 (in Chinese).

Zhang, Shulin. (2009). Introduction of the Technologies of New Energy Auto and Energy-saving in China. Commercial Vehicle, No. 6: 26-29.

\section{Notes}

Note 1 . By the end of 2010, the national civilian vehicle population reached 72.06 million in China and 285 million in U.S. (http://news.cnnb.com.cn/system/2011/02/21/006848538.shtml) (accessed July 1, 2011).

Note 2. See also "China's petroleum and petrochemical industries turn crises into opportunities", China Chemical Industry News, February, 22, 2010.

Note 3. See also Annual Report on Automotive Industry in China, 2008, pp.110.

Note 4. See also 'Policy on Controlling the Emission of Pollutants by the Vehicle in China', by Xingming Li (http://auto.people.com.cn/ GB/3545925.html) (accessed July 1, 2011).

Note 5. See also First Chinese National Pollution Census Bulletin, Xinhua Net (http://www.Xinhua net.com/), February, 25, 2010.

Note 6. See also Xinhua Net (http://www.Xinhua net.com/), April, 22, 2009.

Note 7. That is National High-tech R\&D Program proposed by several famous scientists in March, 1986.

Note 8. See also http://auto.cnfol.com/090106/169,1684,5301706,00.shtml (accessed July 1, 2011).

Note 9. See also http://news.ddc.net.cn/newsview.aspx?id=26610 (accessed July 1, 2011).

Note 10. See also http://auto.sina.com.cn/car/2010-01-18/09595598

Note 11. See also http://sc.sina.com.cn/auto/newcar/2010-01-21/085810418_2.html (accessed July 1, 2011).

Note 12. See also China Energy News, May, 18, 2009.

Note 13. According to the speech by Wei Miao in Beijing University Guangzhou New Year's Forum, January, 9, 2010 (http://finance.sina.com.cn/hy/20100109/16427219276.shtml) (accessed July 1, 2011).

Note 14. See also Beijing Youth Daily, December, 9, 2009.

Note 15. According to the interview "Ouyang Minggao: Starting from 2 Terminals to the Central" (http://auto.sohu.com/20091021/n267596683.shtml) (accessed July 1, 2011). 